\title{
Associating Educational Psychology Theories in a Curriculum to maximise Student Participation
}

\author{
Cecilia. K.Y Chan \\ Centre for the Enhancement of Teaching and Learning \\ The University of Hong Kong \\ Hong Kong
}

Received: April 25, 2012 Accepted: May 22, 2012 Published: August 1, 2012

doi:10.5296/jse.v2i3.1712 URL: http://dx.doi.org/10.5296/jse.v2i3.1712

\begin{abstract}
Psychology has existed for a long time in the academic field of engineering education although many teachers are unaware or unfamiliar with the psychological theories and associated terms. This paper discusses how psychology is related to engineering education, from the development of the curriculum to the delivery and assessment process and how each student and teacher affiliate with one another. It pays particular attention to the development of an electrical engineering first year degree program in Ireland and presents some humanistic approaches in targeting student motivation.
\end{abstract}

Keywords: Psychology, Engineering Curriculum, Student Motivation, Student Retention and Laboratory Training

Psychology is the study of the thoughts and actions of individuals and groups

Educational Psychology is the study of those thoughts and actions as they relate to how we teach and learn 


\section{Introduction to Educational Psychology}

Since the dawn of time, psychology has played an important role in the pedagogical world the development of curriculum, student-teacher affiliation and the process of teaching (and indeed, learning). Great philosophers such as Socrates, Plato and Aristotle have significantly influenced the early account of education. Although it may be argued that their concepts are more of a philosophical nature, these thinkers are well-known for their contributions to the foundation of educational psychology. Berliner (1993) noted that long before the development of educational psychology theories, these philosophers discussed about topics related to education and psychology, such as the role of the teacher, and the nature of learning and the methods of teaching. According to the early theories of the Socratic Method, the principle of teaching lies in the way of questioning learners to understand what they actually know and do not know (Stonehouse, Allison, \& Carr, 2009). Through their application of knowledge and logical reasoning, students can discover new knowledge to solve problems (Paraskevas \& Wickens, 2003). While Socrates developed the method of teaching, his student, Plato, rooted the fundamental concepts of schooling by introducing the models of primary and higher education. He proposed that the goal of primary education is to help students develop elementary knowledge and skills, and those who performed well will be recommended for higher education, leading to an advanced level of intellectual mind and powers (Dupuis, 1985). Aristotle shared a similar view, and believed that education needs to help people enhance their good characters, such as social responsibility, self accountability and moral reasoning (Dupuis, 1985). In addition, Aristotle's of the mind as a blank tablet ("tabula rasa") laid the basis for understanding memory, which is closely related to learning (Walberg \& Haertel, 1992). Many lecturers might have already been practising teaching theories from educational psychology, even though they may not be aware or familiar with the selected psychological theories and related terms. In the engineering discipline, Dewey's (1977) Instrumentalism Theory, Gagne’s Instructional Theory (Gagné, Briggs, \& Wager, 1992) and Skinner's (1965) Shaping Successive Approximations are often employed. Some may be convinced that educational psychology merely yields generic, common sense theories in education but every program in every institutions, no matter a degree, a diploma or a certificate is unique; and the life experiences of each student and lecturer are also unique; thus to understand the problems in education today, we must perform and go deeper into the study of those thoughts and actions as they relate to how we teach and learn. In fact, the following review of the literature suggests that the engineering curriculum is in line with various educational psychology theories.

\section{Engineering Curriculum in Line with Educational Psychology Theories}

A common engineering curriculum involves many pragmatic aspects. After all, what good will it be for an engineer if he or she can only speak of technical concepts and has no actual empirical experiences on the problem in question. The constructivist view of learning (e.g. Bruner, 1986; Dewey, 1977) sees learning as a process of active construction. In the engineering curriculum, hands on projects and practical labs in which learning is combined with concrete activity and pragmatism is in line with Dewey's Instrumentalism theory which emphasizes on the importance of hands-on experience in students' construction of new ideas. 
Practical work in engineering is usually set on a controlled environment at least in their fresh years, and as the level of reasoning and understanding of the learner develops, the level of difficulty increases and a new target within the zone of proximal development (Vygotsky, 1978 ) is set. The zone of proximal development is a component of Vygotsky's (1978) social constructivist theory, which proposed that learning is a social process, and learning under appropriate guidance and/or through collaboration with others will help learners achieve more than what they can individually. The use of problem-based and project-based teaching strategies in engineering education is aligned with this theory, such that team work and group discussions require interaction with peers. In Purzer's (2009) study which observed team discussions on how to solve a particular design problem in a first year engineering classroom, it was found that positive team environment is related to higher achievement score.

Most students choose to become engineers because they like the ideas of inventing, designing, building and creating "their own innovative visions". But sometimes, their early experiences in college can lead to expectations which are quite the opposite, as there are lots of theoretical studies and set practical "follow the procedures" labs involved. In fact, we can almost say there are scarcely any wild, brainstorming sessions in the first-year of many universities. However, this is a mandatory process of the learning curve. In fact, it models the three principles in Gagne’s Instructional Theory (Gagné, Briggs, \& Wager, 1992) , that is providing instruction on the set of component tasks that build toward a final task; ensuring that each component task is mastered and sequencing the component tasks to ensure optimal transfer to the final task. Students must first learn the basic knowledge in engineering and science, after all, 'how could we run if we don't know how to walk!'. This idea is well-reflected in the interdisciplinary core laboratory sequence in Auburn University, introduced by Roppel et al. (2000). This laboratory component involved six core electrical engineering (EE) labs, to be taken in a sequence, such that the first few labs were designed to familiarize students with proper lab procedures and practice, while the later labs move on to introduce more integrated EE concepts.

Skinner's (1965) concept of shaping proposed that one's behaviour gradually changes as a result of progressive reinforcement. In fact, Skinner's idea is based on Thorndike's (1927) law of effect. Thorndike (1927) demonstrated his law of effects using the renowned puzzle box and cat, and then observed its behaviour as it tried to escape in order to obtain some food. After many attempts of trial and error, the time for the cat to succeed each time was gradually reduced. He believes that all learning involves the formation of connections, and connections were strengthened according to the law of effect. However, we should note that his theories are based upon ultimate controlled behaviour on animals using the same environment every time, while trial and error behaviour will generally improve the slope of the learning curve, we human beings may not concur, as repetitive empirical projects can be infuriating and tiresome.

In Waks \& Sabag's (2004) study, which compared the achievement of engineering students in project learning and traditional laboratory, it was found that students who were involved in design activities and the repairing of malfunctioning circuit obtained better test scores than students who were involved in the building of an electronic circuit and writing of lab reports 
in the traditional lab sessions. Findings from this study suggested that for some students, experiences from follow the procedures laboratories (Chan, 2012) can be quite a turn-off. They forget the reasons why they like engineering and moreover, begin to question their choices of the college programmes. Traditional labs are obligatory for students to learn and to comprehend the fundamentals but at the same time, students should be encouraged to utilize their creative talents and never disheartened and denied by their imagination; as there is no right or wrong in creativity, and it is alright to make mistakes, after all, 'Rome was not built in one day', only with trials and errors, new inventions will be invented.

De Bono (1970) believes that traditional thinking and standard solutions may no longer work for this evolving world and lateral thinking may be a way to go. Taking a pragmatic approach, he identified four factors associated with lateral and creative thinking, namely recognizing the dominant ideas that polarize perception of a problem, searching for different ways of looking at things, relaxation of rigid control of thinking and use of chance to encourage other ideas (Proctor, 1999). The application of De Bono's (1970) concept of lateral thinking can be observed in problem-based learning and project-based learning in engineering education. Both types of learning approaches encourage students to consider a problem from different perspectives and require them to go through the process of trial and error in their exploration of ideas (Mills \& Treagust, 2003).

Many top banks or large consultancy firms choose to employ students and graduates from a diverse range of disciplines. They have no preference on whether the students majored in engineering, business, English literature or any other disciplines. In fact, the selection procedures merely concern their academic accomplishments and more importantly on their generic skills, such as how sharp-witted, creative, inventive, communicative and imaginative they perform given a real life problem (Chan, 2012). It is therefore crucial to develop a curriculum or at least part of a curriculum that will allow students to think out of the box, to explore their natural design creativity in a freeform, brainstorming manner rather than a structured formal approach for problem solving. This is essential as students can sometimes become too accustomed to the way they are being taught - learning by rules and by theories in a controlled manner, and forgetting the real him or her. In reality, it is not just students, a lot of times, we get into the habit of doing things one way, a way that we have grown comfortable with and we find it difficult to change this customary routine, even though it may not always be the best way. Quality assurance of any programme is also an important part of curriculum development as it provides feedback from both learners and teachers. Carl Rogers, a Humanistic psychologist said, 'Unless I had a need to demonstrate my own cleverness and learning. I would be better to rely upon the client for the direction of movement'(Rogers, 1967, p.12). Rogers' works were more on the personality development and experimental learning of the learner but he accentuated the importance of learning to learn and an openness to change.

Based on a case study, this paper aims to discuss how psychology is related to engineering education, in terms of the type of pedagogies and assessment used in an engineering course. 


\section{Context}

The third level education institution where the study was conducted is a large public Institute of Technology (IoT) in Ireland. The IoT has an enrolment of nearly 21,000 undergraduate students, and only 1000 postgraduate students. Like most institutes of Technology or Polytechnic colleges around the world, the history of the college is less research intensive and most of the degree programmes are more practical in nature. The programme in question is a three-year ordinary electrical engineering degree programme, the enrolment criteria requires very low school-leaving results. The average class size was about 35 students. These students aged from 17 years old to 40 years old with diverse backgrounds. With the diverse backgrounds and poor student standards, student engagement and retention have suffered critically. Thus, in order to improve these matters, significant modifications have been introduced to the programme particularly in the laboratory sessions.

\section{Method}

Participant observation (Cohen, Manion, \& Morrison, 2011) was conducted in the form of laboratory observation and observation of the pedagogies and assessment involved in the curriculum structure.

Laboratory observation was first made in a particular two hours electricity laboratory of a first year electrical engineering ordinary degree programme. The lab involved the use of our favourite child play blocks - LEGOS, these LEGOS blocks were like ordinary LEGOS except it can be attached to a microprocessor and motors, capable of being programmed for any kind of motions and movements. These LEGOS are parts of the Mindstorms LEGO range, also fabricated by the company LEGOS. The students were given a lab assignment to build a 3-wheel vehicle using the blocks in any way they desire but must has a steering ability and capable to move in a circular path. A very short questionnaire was formulated to justify the observations. The questionnaire merely included three three-point Likert scale questions asking if they would prefer this type of laboratory session in future sessions, do they feel this session provide them the opportunity to be creative and did they learn how the microprocessor work. All 38 students answered the questionnaire.

\section{Results and Discussion}

\subsection{Pedagogies}

The incorporation of LEGO Mindstorms into engineering courses is often based on three main pedagogical objectives: 1) to allow students to explore engineering issues and apply knowledge learnt in lectures, 2) to encourage students to solve real engineering problems creatively, 3) to let students have fun with hands-on experience (Gage \& Murphy, 2003).

During the laboratory observation, it was observed that the students were much more enthusiastic and passionate as compared to their normal weekly laboratory assignments. It was surprisingly strange as this lab was held on the last week before the Christmas holidays for two groups of thirteen first year ordinary degree students and also on the first week after the Christmas holidays for the remaining group of twelve students. Normally, most students 
would have lost concentration or comprehension and display signs of disinterest after approximately forty minutes of the lab if not before, and not mentioning it is near Christmas time. But for this particular lab, they continued to be very keen and excited throughout and expressed that they wish to stay beyond the two hours period. Students were encouraged to create and design their vehicles any way they wished, and they loved it! Supporting our observation, results from the short questionnaire suggested that young engineering students enjoy designing and building things especially when they are given the opportunity to exercise their own ideas. Consistent with this finding, previous studies (e.g. Cyr, Miragila, Nocera, \& Rogers, 1997) also obtained positive feedback from students on the use of LEGOS in laboratory activities.

In addition to the introduction of LEGOS into the laboratory sessions, a group of lecturers applied a small teaching and learning development funding to present students with opportunities to develop their design abilities even as early as first year. The project proposal (Chan \& Coyle, 2004) was to implement an unstructured informal approach to design and build an engineering device which is related to a real life application by trial and error, given a common theme, a set of rules and a box of simple engineering items such as motors, LEDs, wires, batteries and resistors. Students were expected to build the application using any creative and recycled materials such as old plastic bottles, metal pieces etc [reverse engineering may be employed]. An award was given to the best design which satisfied the rules and conditions among the class, this included a presentation and demonstration of the project. Most students participated in the competition due to the competitive nature and also due to their interests in developing their own ideas. An example of the final product was first built and presented to the students to give them some general ideas of the expected product. At the time this design project proposal was established, the author did not realise or understand the implication of educational psychology, although it is now clear to the author that various educational psychology theories are well-illustrated in the project.

Firstly, the use of real life experience, objects and visual tools such as graphics are all parts of Vygotsky's (1978) educational concepts. Based on Vygotsky's notion of zone of proximal development, collaboration with people and the use of artifacts (e.g. books, video, computer) will enable students to go beyond their current level of competence (Brown, 1992; John-Steiner \& Mahn, 1996). Secondly, both the design competition and the use of LEGOS in the laboratory sessions provide students with opportunities for meaningful learning through hands-on experience of creating a product. This coincides with both Bruner's (1986) and Dewey's (1977) idea of learning as an active process in which students construct new ideas or concepts based on their current knowledge and engage in meaningful and relevant activities which allow them to apply the concepts they endeavour to learn. Furthermore, students were given a high level of autonomy in the designing of the 3-wheel vehicle and in the design competition. Provision of an autonomy-supported learning environment to improve learning is supported by the works of Deci \& Ryan (1985) and Rogers \& Freiberg (1994). Deci \& Ryan (1985) proposed that learning environment that supports autonomy facilitate the development of intrinsic motivation and increases students' conceptual learning and creative thinking. Similarly, Rogers \& Freiberg (1994) stated that learning is facilitated 
and creativity is initiated when a student participates completely in the learning process and has control over its nature and direction.

\subsection{Assessment}

Apart from introducing hands-on activities, in the ordinary electrical engineering degree programme at the IoT, significant modifications have been made to the assessment methodologies with emphasis on end-of-year examinations reduced and greater emphasis being placed on continuous assessment elements throughout the programme. These changes were made in response to the comments from students and staff through the course evaluation feedback. The continuous assessment component in the majority of the modules now has at least a 50\% weighting, with some modules being $100 \%$ continuously assessed. It was agreed that by actively engaging the student throughout the semester and rewarding effort accordingly, the learning experience was greatly enhanced and the students were more likely to succeed in the programme. Also feedback for and from students would be more effectively exercised as the feedback were provided in a prompting manner.

The use of continuous assessment is consistent with Skinner's idea, illustrated in a commonly cited quotation: "The whole process of being competent in any field must be divided into a very large number of very small steps, and reinforcement must be contingent upon the accomplishment of each step.” (Skinner, 1954, as cited in Shepard, 2000). This is also evidenced in the assessment of an experiential community service learning project (Chan, 2011). Engaging students through continuous assessment and feedback can be considered as step-by-step reinforcement of desirable learning behaviour in students.

\section{Implications}

\subsection{Educational Benefits}

The proposed project design competition was conducted among a class of fifty first year students. For these students, academic issues are not their initial priorities. This mentality is likely to have developed from secondary level where their academic attainments were not of high calibres, and there is a lack of desire and pressure on needs for recognition and building of self-fulfilment. Student Retention problems often arise due to unawareness and uncertainty on college choices and future prospects. The outcomes of the project design competition has led to many benefits, related to student retention and motivation, which have seemingly been always at the tips of our tongues. These educational benefits are identified as follow:

Allowed young Engineering students to run-free, explore and continue with their natural design creativity and ideas, and more importantly, to enjoy and develop interests in their academic life;

Widened and encouraged student projects participation from as early as $1^{\text {st }}$ Year;

Established a balance between students' expectations in college and the nature of the academia;

Introduced competitiveness in a fun and undemanding way; 
Allowed students to interact with one another, associate with one another through common grounds and interests; a good approach to ease them into college life

Encouraged family support and enhanced closeness.

In fact, there are plans to hold the next design competition across Christmas, so that students can bring home the design kit at Christmas time and demonstrate it to their family. Noting the educational benefits of the design competition, it can be consider as a potential student retention strategy which may lead to future developments for other departments and academic communities

\subsection{Other pedagogical implications}

How a teacher delivers his or her course greatly influence how successful and motivated learners can be. It is extremely challenging to question how a teacher should teach, because every teacher has his or her own individuality and quality in his or her field of teaching.

In field areas such as Engineering and Science, teachers are expected to know his or her subject, but at the same time, they must also keep an open mind since technological know-how are constantly being explored and not all things known to man have yet been fully comprehend and explained. In fact, if we think about it, people from early antiquity generally believed the earth was flat, they thought the world was portrayed as a flat disk floating in the ocean. By classical times an alternate idea of a spherical Earth known as geoid appeared. But as the science of geodesy measured Earth more accurately, the shape of the geoid was found not to be a perfect sphere but to approximate an oblate spheroid (Morrison, 1972). Teachers should change their teaching from mindless learning to a more open-minded learning environment, so students can manipulate information and allow students to raise doubts. They shouldn't be uncomfortable when students challenge their understanding and explanation; in fact they should use this opportunity to open up interactive question and answer sessions among the class to stimulate the rest of the students. Fifty minutes can be a long time to sustain anybody's interest especially when the students are only 17 and 18 years old. Nobody wants to just sit and listen whole day long, thus sometimes it is more effective to make it a 2-way conversation. Call on students for answer to shake students out of their passivity. In the Socratic teaching method, Socrates stresses the power of dialogue - the joint exploration of a subject - 'knowledge will not come from teaching but from questioning' (Hare, 1989). Moreover, Langer (1998), author of the Power of Mindful Learning, believes that questioning, not accepting, is one of the keys to a lifelong ability to learn and grow. Being mindful is an important ability in a learning process. We have to question given information from different perspectives and not simply accept it without critical thinking. As knowledge is limitless, we should develop a questioning mindset to avoid mindless learning (Langer, 2000). Thus, we need to provide opportunities for students to practise and to experience trials and errors but, the curriculum needs to be well-designed such that there are opportunities for creativity and problem solving and not purely a repetition of procedures. This would ultimately help to widen student participation and maintain student interests, as a role of an engineering teacher to assist student retention. And ultimately, establish balances between student expectations as 
engineers and the less-exciting learning facts in college; maybe this will assist them to answer some of the most common queries in early student withdrawals.

It is undisputable that motivation is the primary fact that drives a student in a particular achievement situation. This motivation can be divided into either task- or ego-oriented (Nicholls, 1984). A student who is task-oriented is interested in learning a subject for his or her own sake. These students tend to evaluate their performance on an internal basis. They tend not to make comparisons to an external norm of performance provided by a peer group. On the other hand, students who are predominantly ego-oriented are only interested in how their performance looks in the eyes of others. All comparisons are therefore made to an external peer group. Unfortunately, most of our students particularly in their early years of higher education tend to incline more to the ego-oriented direction. This mentality is likely to have developed from our educational system which unknowingly fosters an ego orientation by assigning grades on a normative basis.

Many methods have been utilised to direct student learning to a more intrinsic motivating attitude in the engineering discipline. Teachers have been encouraged to apply their teaching theories to real life situations while making their delivery method more interactive, visual and graphical as according to Vygotsky (1978) and Piaget (1971) since abstract concepts are more difficult to grasp. Often it is beneficial to relate the theories with a story, a riddle or even a trick, which will assist the students to understand, think and remember better. For example, in electrical engineering, a lecturer was trying to explain the theories behind voltage, current and resistance. She knows all her students have an idea what a socket is, thus she indicated that voltage is supplied from the socket and explained: 'If I put my finger inside the socket, a current will flow through me and will probably electrocuted me depending on how much voltage is supplying from the socket.' As you can expect, all the students laughed. Then she continued to explain 'However, if I get John (a student in the class) to stick his finger up the socket first and then I hold his hand, the current is now flowing through John and then me, John is now acting as an resistor between the socket and I, the amount of current flowing into me is now smaller, so I probably will get electrified but not necessarily electrocuted! Well, however, I am not too sure about John!' Again, there is a roar of laughter in the class. This kind of interactive teaching helps the students to understand better. Lave \& Wenger (1991) emphasizes the importance of language in learning, but not necessarily in the form of direct explanation. Language is important because part of becoming a legitimate participant requires an understanding of how to talk in the manner of full participants.

Naturally, positive reinforcement is always a drive for upbeat behaviour, as we humans tend to be motivated when our performance is followed by rewards but we should beware of diminishing returns. It is interesting to note, adequate amount of competitiveness may also be categorised as a type of positive reinforcement. And as mentioned previously, regardless of how poor the accomplishment of the creative matter is, it should not be denied. Aversive stimulus or negative reinforcements should not be practised since 'Bad do worse because the bad is rewarded. And the good do better because the good is rewarded also'.

Regardless of the method of delivery, I personally believe 
'you have only taught, if the students can fully understand and apply what you have taught him or her.'(Chan \& Coyle, 2004)

\section{Conclusion}

The development of any curriculum must be carefully thought out in line with modern trends in education delivery, industrial, society and career bearings and the capability and motivational level of the learners. Tertiary education is not all about success in academia, it is just another stage to prepare the youths of today before they step into the society, to teach these youths to become not just successful engineers (if possible) but more importantly, to help them to develop their minds and personal selves, to think and solve problems analytically - think before act, to produce results more effectively, to interact with people, to be more adaptable and so as to cope with stress in different situations in life. It doesn't matter if they don't possess the highest Intelligence Quotient - I.Q. but allowing college experiences to develop more Emotional Quotient - E.Q., that is the jewel of third level education.

Major concern over student recruitment and retention in the field of electrical engineering has grown in recent years. Students who are interest in this field are diminishing by years and degree and diploma courses are in serious threat and danger of being closed down. The ordinary degree programme in electrical engineering in a third-level institution in Ireland has gone through some major transformations in order to assist and reduce this ever-increasing level of student withdrawal. As science subjects are becoming even less popular for secondary level pupils, we feel the need to redouble our efforts to retain those students that we have managed to attract and naturally, create strategies for student recruitment in order to attract future candidates into the engineering discipline.

As the world is evolving all the time, and in today's world, there are way more social disturbances for students, all of these are now an integrated part of our life, and it cannot be changed. But as educators, we must try to motivate them, rather than compare today's students with yesterday's students, we must accept that the generation has changed and if one teaching method doesn't work; a new approach must be adopt. Educational system and psychology should go hand in hand and aim towards a more humanistic and flexible approach to facilitate learning. And to understand the problems in education today, we must perform and go deeper into the study of those thoughts and actions as they relate to how we teach and learn.

Plato (Seller, 2010, p.25) believed and demonstrated,

'Educators must have a deep care for the well-being and future of those they work with. Educating is a moral enterprise and it is the duty of educators to search for truth and virtue, and in so doing guide those they have a responsibility to teach.'

\section{References}

Berliner, D. C. (1993). The 100-year journey of educational psychology: From interest to disdain to respect for practice. In A. Anastasi, T. Fagan \& G. R. VandenBos (Eds.), Exploring 
applied psychology origins and critical analyses (1st ed., pp. 39-78). Washington, DC: American Psychological Association. http://dx.doi.org/10.1037/11104-002

Brown, A. L. (1992). Design experiments: Theoretical and methodological challenges in creating complex interventions in classroom settings. The Journal of the Learning Sciences, 2(2), 141-178. http://dx.doi.org/10.1207/s15327809jls0202_2

Bruner, J. S. (1986). Actual minds, possible worlds. Cambridge, Mass.: Harvard University Press.

Cecilia Ka Yuk Chan (2011): Assessment for community service types of experiential learning in the engineering discipline, European Journal of Engineering Education,

Chan, C. (2012). Laboratory learning. In N. M. Seel (Ed.), Encyclopedia of the sciences of learning (pp. 1705-1708). New York: Springer.

Chan, C.K.Y. (2012) Identifying and understanding the graduate attributes learning outcomes in a case study of community service experiential learning project', Int. J. Continuing Engineering Education and Life-Long Learning, Vol. 22, Nos. 1/2, pp.148-159

Chan, C., \& Coyle, E. (2004). Natural, creative, brainstorming "scrapyard challenge" design project. Paper presented at the 33 International Symposium IGIP/IEEE/ASEE, Fribourg, Switzerland.

Cohen, L., Manion, L., \& Morrison, K. (2011). Case studies Research methods in education (7th ed., pp. 253-263). London ; New York: Routledge/Falmer.

Cyr, M., Miragila, V., Nocera, T., \& Rogers, C. (1997). A low-cost, innovative methodology for teaching engineering through experimentation. Journal of Engineering Education, 86(2), 167-171.

De Bono, E. (1970). Lateral thinking: A textbook of creativity. London: Ward Lock Educational.

Deci, E. L., \& Ryan, R. M. (1985). Intrinsic motivation and self-determination in human behavior. New York: Plenum Press.

Dewey, J. (1977). Experience and education. New York: Collier Books.

Dupuis, A. M. (1985). Philosophy of education in historical perspective. Lanham, MD: University Press of America.

Gage, A., \& Murphy, R. R. (2003). Principles and experiences in using LEGOS to teach behavioral robotics. Paper presented at the 33rd ASEE/IEEE Frontiers in Education Conference, Boulder, CO.

Gagné, R. M., Briggs, L. J., \& Wager, W. W. (1992). Principles of instructional design (4th ed.). Fort Worth: Harcourt Brace Jovanovich College Publishers.

Hare, R. M. (1989). Plato. Oxford: Oxford University Press. 
John-Steiner, V., \& Mahn, H. (1996). Sociocultural approaches to learning and development: A Vygotskian framework. Educational Psychologist. Special Issue: Recent and emerging theoretical frameworks for research on classroom learning: Contributions and limitations, 31(3-4), 191-206.

Langer, E. J. (1998). The power of mindful learning. Cambridge, MA: Da Capo Press.

Langer, E. J. (2000). Mindful learning. Current Directions in Psychological Science, 9(6), 220-223. http://dx.doi.org/10.1111/1467-8721.00099

Lave, J., \& Wenger, E. (1991). Situated learning: Legitimate peripheral participation. Cambridge, England: Cambridge University Press.

Mills, J. E., \& Treagust, D. F. (2003). Engineering education: Is problem-based or project-based learning the answer?

Morrison, F. (1972). Density layer models for geopotential. American Scientist, 60(2), 229-236.

Nicholls, J. G. (1984). Achievement motivation: Conceptions of ability, subjective experience, task choice, and performance. Psychological Review, 91(3), 328-346. http://dx.doi.org/10.1037/0033-295X.91.3.328

Paraskevas, A., \& Wickens, E. (2003). Andragogy and the socratic method: The adult learning perspective. Journal of Hospitality, Leisure, Sport \& Tourism Education, 2(2), 4-14. http://dx.doi.org/10.3794/johlste.22.20

Piaget, J. (1971). Science of education and the psychology of the child. London: Longman.

Proctor, T. (1999). Lateral thinking and associated methods Creative problem solving for managers (pp. 132-155). London; New York: Routledge. http://dx.doi.org/10.4324/9780203259214

Purzer, S. (2009). Learning engineering in teams: Perspectives from two different learning theories. Paper presented at the Research in Engineering Education Symposium, Palm Cove, QLD.

Rogers, C. R. (1967). On becoming a person: A therapist's view of psychotherapy. London: Constable.

Rogers, C. R., \& Freiberg, H. J. (1994). Freedom to learn (3rd ed.). New York: Merrill.

Roppel, T. A., Hung, J. Y., Wentworth, S. W., \& Hodel, A. S. (2000). An interdisciplinary laboratory sequence in electrical and computer engineering: Curriculum design and assessment $\begin{array}{llll}\text { results. Ieee Transactions on } & \text { Education, 43(2), } 152 .\end{array}$ http://dx.doi.org/10.1109/13.848066

Seller, M. (2010). The role of adult learning - lifelong learning or lifelong education? International Journal of Instructional Technological \& Distance Learning, 7(10), 25-30. 


\section{Macrothink}

Journal of Studies in Education

ISSN 2162-6952 2012, Vol. 2, No. 3

Shepard, L. A. (2000). The role of assessment in a learning culture. Journal of Education, 189(1/2), 95-106.

Skinner, B. F. (1965). Science and human behavior. New York: Free Press.

Stonehouse, P., Allison, P., \& Carr, D. (2009). Aristotle, Plato, and Socrates: Ancient Greek perspectives on experiential learning. In T. Smith \& K. C. (Eds.), Beyond Dewey \& Hahn: Foundations for experiential learning (pp. 29-41). Wisconsin: Raccoon Institute Publications.

Thorndike, E. L. (1927). The law of effect. The American Journal of Psychology, 39, 212-222. http://dx.doi.org/10.2307/1415413

Vygotsky, L. S. (1978). Mind in society: The development of higher psychological process. Cambridge, Mass.: Havard University Press.

Waks, S., \& Sabag, N. (2004). Technology project learning versus lab experimentation. Journal of Science Education and Technology, 13(3), 333-342. http://dx.doi.org/10.1023/B:JOST.0000045460.06506.43

Walberg, H. J., \& Haertel, G. D. (1992). Educational psychology's first century. Journal of Educational Psychology, 84(1), 6-19. http://dx.doi.org/10.1037/0022-0663.84.1.6 